\title{
Status of cytoskeleton proteins during initial germination of dark-grown pea (Pisum sativum) seedlings
}

\author{
Mahmoud F.M. Moustafa \\ Botany Department, Faculty of Science, South Valley University, Egypt \\ Fax +20965213383; e-mail: hamdony@yahoo.com
}

\begin{abstract}
Summary
Original homogenate, supernatant and pellet of $250 \mathrm{xg} 27000 \mathrm{xg}$ for 30,45 and 69 hours germinated Alaska pea seeds (Pisum sativum L. var. Alaska) were tested to investigate the status of cytoskeleton proteins in embryo and its different parts. All samples were treated by cytoskeleton-stabilizing buffer, electrophoresed and blotted on to membranes. Blots probed with antibodies to actin, alpha-tubulin and beta-tubulin, revealed bands with apparent molecular weights of $42 \mathrm{kDa}, 46 \mathrm{kDa}$, and $50 \mathrm{kDa}$ respectively. In all cases, sedimentable tubulin and actin were found maximally in the $27000 \mathrm{xg}$ and $250 \mathrm{xg}$ pellet and less in supernatant of $250 \mathrm{xg}$ and $27000 \mathrm{xg}$. Amount of actin and tubulin in embryos were a highest in 30 hours germinated Alaska pea seeds and less in 45 hours and much more less in 69 hours. By 96 hours, abundance of cytoskeleton proteins in different fractions of the stems much more high than the prophylls, while in the roots there were very small amounts of all cytoskeleton proteins. Various streptavidin-binding proteins (SBP) and actin like proteins (ALP) were also found in all harvested parts. The present results suggest that cytoskeleton proteins are physiologically important and strongly indicate a crucial role for the differentiation and development of Alaska pea seedlings.
\end{abstract}

Key words: cytoskeleton, actin and tubulin.

\section{Introduction}

Actin filaments and microtubules are the major component of the plant cytoskeleton (Bershadsky and Vasilev 1988), these components associate with one another and with other cytoskeletal components (Griffith and Pollard 1978; Solomon et al. 1979; Walker et al. 1985), in animal cell with various membrane systems (Moosker and Tilney 1975; Hesketh and Pryme1988) and in plant cells (Abe and Takeda 1986, 1989; Hepeler et al. 1990).

Cytoskeleton fulfills almost all physiological metabolism in the plant cell. It acts as traffic for the movement of Golgi apparatus (Boevink et al.1998). There is a strong relation between the presence of peroxisomes and cytoskeleton elements (Mathur et al. 2002), movement of mitochondria on F-actin (Van Gestel et al. 2002). Actin filament is the main cause for myosin motor (DePina and Langford 1999) and chromosome segregation during mitosis (McIntosh 1994). Microtubules and microfilaments are intimately involved during cell fusion (Abe and Takeda 1986, 1989). There is an intimate association between microtubules which present in the cortex and plasma membrane (Shibaoka 1994), these cortical microtubules are highly organized to provide spatial information to direct the orderly deposition of cellulose microfibrils within the plant cell wall (Williamson 1991; Cyr 1994). Mechanism of opening and closing of the stomata modulated by actin filaments (Hwang et al. 1997) and likely establish the connections between cells (Aaziz et al. 2001). Transduction stimulation of gravitropic in root cell mainly organized by actin filament (Braun et al. 2004).

To study the status of cytoskeleton proteins, cytoskeleton-stabilizing buffer (CSB) was used (Abe and Davies 1991), whereas this buffer will permit an isolation intact fragment of different cytoskeleton proteins without damaging. We used antibody generated against actin, alpha-tubulin, and beta-tubulin to know changes taking place 
on actin and tubulin during the early stage of germination of Alaska pea seeds (Pisum sativum L. var. Alaska). Cytoskeleton proteins were immunologically detected in all investigated samples, and that will give more information about the relationship between plant cell metabolism and cytoskeleton proteins during germination course of Alaska pea.

\section{Materials and methods}

\section{Isolation of cytoskeleton proteins from germinated Alaska pea seeds}

Seeds of Alaska pea (Pisum sativum L. var. Alaska) were imbibed for 10 hours and then germinated in vermiculite in plastic boxes in a dark room for 69 hours at 21-23 ${ }^{\circ} \mathrm{C}$, as described (Abe and Davies 1991).

At each time point of 30, 45, 69 hours after germination, three grams of intact embryonic tissue or separate prophylls, stems, cotyledonary stalks and roots were dissected from the cotyledons, collected on ice, and ground with a mortar and pestle in 7 volumes of cytoskeleton-stabilizing buffer (CSB) consisting of $5 \mathrm{mM}$ HEPES ( $N-2-$ hydroxyethylpiperazine- $\mathrm{N}$-2-ethanesulfonic acid)-KOH (pH 7.5), $10 \mathrm{mM} \mathrm{Mg} \mathrm{(OAc)2,}$ $2 \mathrm{mM}$ EGTA (ethylenebis (oxyethylenenitrilo) tetraacetic acid), and 1 $\mathrm{mM}$ PMSF (phenylmethylsulphonyl fluoride) with the addition of $0.5 \%$ PTE (polyoxyethylene-10-tridecyl ether) and homogenate was filtered through Miracloth (Calbiochem, San Diego, CA, USA). To study the sedimentability of cytoskeleton proteins, the filtrate centrifuged at $250 \mathrm{xg}$ for 5 minutes and $27000 \mathrm{xg}$ for 15 minutes.

\section{Gel electrophoresis and Western blotting}

Samples were electrophoresed on SDSPAGE as described (Abe and Davies 1991, 1995). The sample buffer (10 $\mathrm{mM}$ Tris$\mathrm{HC1}$; pH 6-8, 2\% 2-mercaptoethanol, and $2 \%$ lithium dodecyl sulfate) was prepared as a $2 x$ stock. We used lithium dodecyl sulfate (LDS) instead of sodium dodecyl sulfate (SDS) in the sample buffer because lithium dodecyl sulfate does not precipitate at a low temperature when samples were kept in the refrigerator before use. The stock was mixed with an equal volume of homogenate or resuspended pellet or supernatant and the mixture was boiled for three minutes. After electrophoresis the gels were blotted onto a PVDF membrane (ImmobilonTM Transfer Membranes, Millipore). Monoclonal antibodies raised against actin (N. 350), alpha-tubulin (N. 356), and beta-tubulin (N. 357) in mouse ascites fluid, obtained from Amersham were used as the primary antibodies. The binding of these primary antibodies to their antigens was detected by indirect immunoblotting with biotinylated goat antibody raised against mouse Ig as the secondary antibody (Amersham). To detect the binding of the secondary antibody a streptavidin-conjugated alkaline phosphatase (Amersham) was used, using 5-bromo-3chloro-indolyl phosphate and Nilroblue tetrazolium as substrates.

\section{Results}

\section{Alpha-, beta-tubulin and actin in embryos of 30 and 45 hours germinated Alaska pea seeds}

Embryos dissected from cotyledons of 30 hours germinated Alaska pea were ground in cytoskeleton-stabilizing buffer and Immunodetection for cytoskeleton proteins was performed (Figure 1A). There are three major bands were apparent in uncentrifuged homogenate corresponds to $42 \mathrm{kD}$ for actin, $46 \mathrm{kDa}$ for alpha-tubulin and $50 \mathrm{kDa}$ for beta-tubulin (lane 1). In contrast, none of these bands were apparent in $250 \mathrm{xg}$ supernatant (lane 2), while a major three bands at $42 \mathrm{kDa}, 46 \mathrm{kDa}$ and $50 \mathrm{kDa}$ were found in $250 \mathrm{xg}$ pellet and both in $27000 \mathrm{xg}$ pellet and supernatant (lanes 3, 4 and 5). 39 $\mathrm{kDa}$ actin like protein (ALP) appeared in uncentrifuged homogenate, $250 \mathrm{xg}$ pellet, and both in $2700 \mathrm{xg}$ pellet supernatant (lanes 1,3 and 5). $78 \mathrm{kDa}$ and $110 \mathrm{kDa}$ streptavidin-binding proteins were apparent in uncentrifuged homogenate, $250 \mathrm{xg}$ pellet and in $27000 \mathrm{xg}$ pellet and $27000 \mathrm{xg}$ supernatant (lanes 1, 3, 4, and 5) respectively.

Within embryos of 45 hours germinated Alaska pea seeds (Figure 1B), two apparent bands were evident corresponding to alpha-, and beta-tubulin, while actin was detected in a very low amount in uncentrifuged homogenate (lane 1). In $250 \mathrm{xg}$ supernatant, alpha-tubulin detected in a very low amount 
while beta-tubulin and actin were not apparent (lane 2). Alpha- and beta-tubulin were apparent within the pellet of $250 \mathrm{xg}$ and $27000 \mathrm{xg}$ as well as supernatant of $27000 \mathrm{xg}$ (lanes 3, 4 and 5) respectively. $110 \mathrm{kDa}$ streptavidin-binding proteins (SBP) was apparent only in $250 \mathrm{xg}$ and $27000 \mathrm{xg}$ supernatants (lanes 2 and 4 ), while $20 \mathrm{kDa}$ actin like proteins was detected only at uncentrifuged homogenate and $27000 \mathrm{xg}$ pellet (lanes 1 and 5).

Cotyledonary stalks and roots of 45 hours germinated embryo (Figure 1C) show very weak appearance of all cytoskeleton proteins. $\quad 110 \mathrm{kDa}$ streptavidin-binding proteins (SBP) was apparent in $27000 \mathrm{kDa}$ supernatant (lane 4). The amount of cytoskeleton proteins were quantified and data given in Table 1. Amount of cytoskeleton proteins mainly depend on time of germination and type of tissue, whereas cytoskeleton proteins more abundant in 30 hours germinated embryos than 45 hours, additionally there is a strong correlation between all the cytoskeleton proteins (Figure 2).

\section{Alpha-, beta-tubulin and actin in the roots of 45 hours and both in embryos and prophylls of 69 hours germinated Alaska pea}

Western blots of roots from 45 hours germinated Alaska pea seeds (Figure 3A) show that alpha- and beta-tubulin appeared equally in uncentrifuged homogenate, 250 $\mathrm{xg}$ pellet, and in $27000 \mathrm{xg}$ pellet (lanes 1, 3 and 5), respectively.

The blots of dissected embryos for 69 hours germinated pea seeds (Figure 3B) reveal that the intensity of alpha- and betatubulin appeared equally within $250 \mathrm{x} g$ pellet (lane 3) and in supernatant and pellet of $27000 \mathrm{xg}$ (lanes 4 and 5), and less in uncentrifuged homogenate and $250 \mathrm{xg}$ supernatant (lanes 1 and 2). $20 \mathrm{kDa}$ actin like proteins was evident in uncentrifuged homogenate (lane 1), $250 \mathrm{xg}$ pellet (lane 3) and $27000 \mathrm{xg}$ pellet (lane 5). $110 \mathrm{kDa}$ streptavidin-binding proteins (SBP) were apparent both in $250 \mathrm{xg}$ and $27000 \mathrm{xg}$ supernatants (lanes 2 and 4).
Within the prophylls of 69 hours germinated Alaska pea seeds (Figure 3C), alpha-, beta-tubulin and actin were present in a high amount in uncentrifuged homogenate, and in $250 \mathrm{xg}$ pellet and 27000 $\mathrm{xg}$ pellet (lanes 1,3 , and 5) respectively, but it detected in a very low amount in $250 \mathrm{xg}$ supernatant (lane 2). $110 \mathrm{kDa}$ streptavidinbinding proteins appeared in all fractions, while $20 \mathrm{kDa}$ actin-like proteins appeared only in $250 \mathrm{xg}$ pellet (lane 3 ).

Densitometry quantification revealed that alpha- and beta-tubulin obtained from embryos decreased during germination and unequally distributed among different organs (Tables 2 and Figure 4).

\section{Alpha-, beta-tubulin and actin in stems, cotyledonary stalks and roots of 69 hours germinated Alaska pea}

Western blots of embryos and its different part including: stems, roots and cotyledonary stalks from 69 germinated Alaska pea seeds were shown in (Figure 5). Within stems of 69 hours germinated Alaska pea seeds (Figure 5A), all cytoskeleton proteins are quite abundant in all fractions except $250 \mathrm{xg}$ supernatant (lane2). $20 \mathrm{kDa}$ actin-like protein was evident in uncentrifuged homogenate and $250 \mathrm{xg}$ pellet (lanes 1 and 3), and $110 \mathrm{kDa}$ streptavidinbinding protein was evident in $250 \mathrm{xg}$ and $27000 \mathrm{xg}$ supernatant (lanes 2 and 4). Within cotyledonary stalks of 69 hours germinated Alaska pea seeds (Figure 5B), all cytoskeleton proteins were present in very low amount in all fractions. $20 \mathrm{kDa}$ actin-like protein present in $250 \mathrm{xg}$ pellet (lane 3) and $110 \mathrm{kDa}$ streptavidin-binding protein in $27000 \mathrm{xg}$ supernatant (lane 4). Within roots of 69 hours germinated Alaska pea seeds (Figure 5C), only alpha- and betatubulin were detected in $250 \mathrm{xg}$ pellet (lane 3 ), while $110 \mathrm{kDa}$ streptavidin-binding protein present in 27000 supernatant (lane 4).

Densitometry quantification of different cytoskeleton bands revealed that the intensity of all cytoskeleton proteins within stems higher than cotyledonary stalks and roots of 69 hours germinated pea seeds (Table 3 and Figure 6). 
Table 1. Abundance of different cytoskeleton proteins in embryos of 30 hours and 45 hours germinated Alaska pea seeds. The individual band corresponding to alpha-, beta-tubulin and actin from Figure 1 were quantified by densitometry and expressed as OD x area of band. "Sum" indicates the summation of all cytoskeleton proteins in each fraction.

\begin{tabular}{|c|c|c|c|c|c|c|}
\hline \multirow[b]{2}{*}{ Tissue Type } & \multirow[b]{2}{*}{ Lane No. } & \multirow[b]{2}{*}{ Fraction type } & \multicolumn{4}{|c|}{$\mathrm{OD} \times \mathrm{mm}^{2}$} \\
\hline & & & $\begin{array}{l}\text { Beta- } \\
\text { tubulin }\end{array}$ & $\begin{array}{l}\text { Alpha- } \\
\text { tubulin }\end{array}$ & Actin & Sum \\
\hline \multirow{5}{*}{$\begin{array}{l}\text { Embryo of } 30 \\
\text { hours }\end{array}$} & 1 & Homogenate & 1.078 & 0.648 & 0.603 & 2.329 \\
\hline & 2 & $250 \mathrm{xg}$ supernatant & 0.161 & 0.099 & 0.038 & 0.298 \\
\hline & 3 & $250 \mathrm{xg}$ pellet & 1.074 & 0.711 & 0.668 & 2.453 \\
\hline & 4 & $27000 \mathrm{xg}$ supernatant & 0.57 & 0.422 & 0.327 & 1.319 \\
\hline & 5 & $27000 \mathrm{xg}$ pellet & 0.608 & 0.823 & 0.755 & 2.186 \\
\hline \multirow{5}{*}{$\begin{array}{l}\text { Embryo of } 45 \\
\text { hours }\end{array}$} & 1 & Homogenate & 0.728 & 0.523 & 0.062 & 1.313 \\
\hline & 2 & $250 \mathrm{xg}$ supernatant & 0.109 & 0.105 & 0.041 & 0.255 \\
\hline & 3 & $250 \times g$ pellet & 0.817 & 0.527 & 0.043 & 1.387 \\
\hline & 4 & $27000 \mathrm{xg}$ supernatant & 0.261 & 0.239 & 0.075 & 0.575 \\
\hline & 5 & $27000 \mathrm{xg}$ pellet & 0.548 & 0.224 & 0 & 0.772 \\
\hline \multirow{5}{*}{$\begin{array}{l}\text { Cotyledonary } \\
\text { stalks and } \\
\text { roots of } 45 \\
\text { hours }\end{array}$} & 1 & Homogenate & 0 & 0.013 & 0 & 0.013 \\
\hline & 2 & $250 \mathrm{xg}$ supernatant & 0.007 & 0 & 0 & 0.007 \\
\hline & 3 & $250 \mathrm{xg}$ pellet & 0.173 & 0.115 & 0 & 0.288 \\
\hline & 4 & $27000 \mathrm{xg}$ supernatant & 0.049 & 0.027 & 0.097 & 0.173 \\
\hline & 5 & $27000 \mathrm{xg}$ pellet & 0.223 & 0.139 & 0 & 0.362 \\
\hline
\end{tabular}
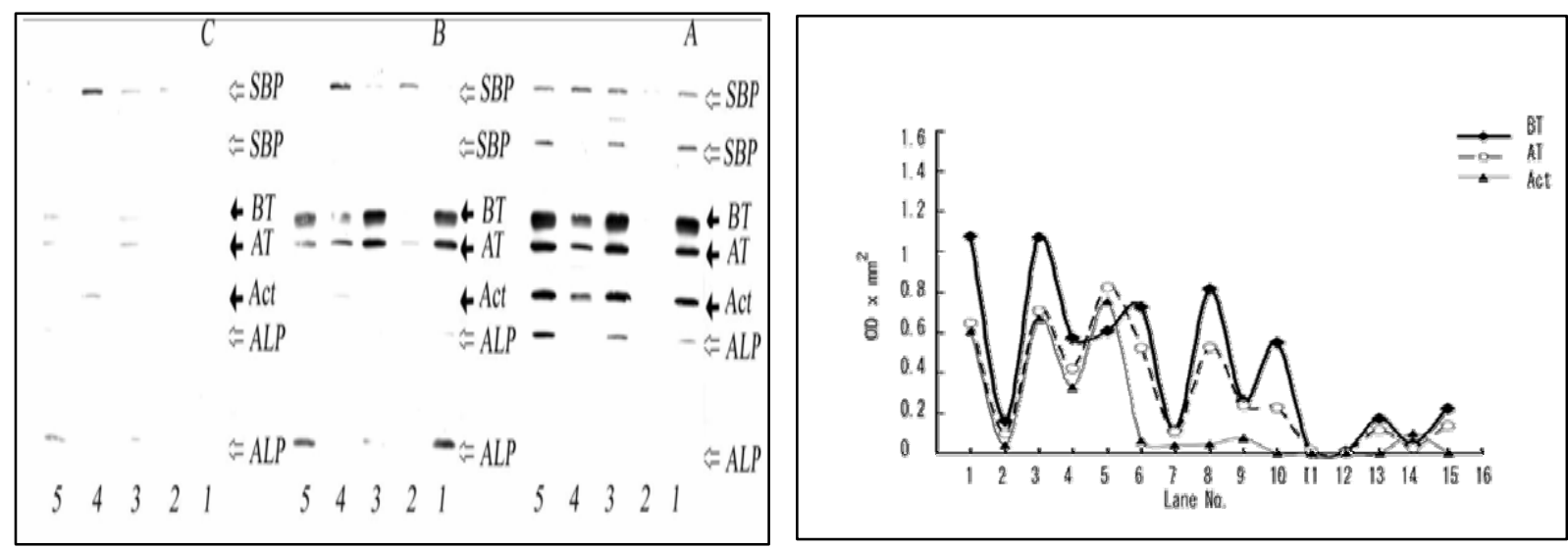

Figure 1. Western blot analysis of cytoskeleton proteins in embryos of 30 hours germinated Alaska pea seeds (A), 45 hours (B) and in cotyledonary stalks and root of 45 hours germinated seed (C). lanes: (1) original homogenate; (2) $250 \mathrm{xg}$ supernatant; (3) $250 \mathrm{xg}$ pellet; (4) $27000 \mathrm{xg}$ supernatant; (5) $27000 \mathrm{xg}$ pellet. Closed arrows point to the positions of Act (actin; $42 \mathrm{kDa}), \mathrm{AT}(\alpha-$ tubulin; $46 \mathrm{kDa}$ ) and BT ( $\beta$-tubulin; $50 \mathrm{kDa})$. Open arrows point to streptavidin-binding proteins (SBP), and actin-like proteins (ALP).
Figure 2. Quantification of Figure 1. lanes (1 5) relationship between individual cytoskeleton protein extracted from embryos of 30 hours germinated Alaska pea seeds; lanes $(6 \sim 10)$ relationship between individual cytoskeleton protein extracted from embryos of 45 hours; lanes (11 15) relationship between individual cytoskeleton protein extracted from cotyledonary stalks and root of 45 hours. lanes: (1, 6 and 11) original homogenate; (2, 7 and 12) $250 \mathrm{xg}$ supernatant; (3, 8 and 13) $250 \mathrm{xg}$ pellet; $(4,9$ and 14) $27000 \mathrm{xg}$ supernatant; (5, 10 and 15) $27000 \mathrm{xg}$ pellet. BT, At, and Act refer to $\beta$-tubulin, $\alpha$-tubulin, and actin, respectively. 
Table 2. Abundance of different cytoskeleton proteins in roots of 45 hours and in embryos and prophylls of 69 hours germinated Alaska pea seeds. The individual bands corresponding to alpha-, beta-tubulin and actin from Figure 3 were quantified by densitometry and expressed as OD x area of band. "Sum" indicates the summation of all cytoskeleton proteins in each fraction.

\begin{tabular}{|c|c|c|c|c|c|c|}
\hline \multirow[b]{2}{*}{ Tissue Type } & \multirow[b]{2}{*}{ Lane No. } & \multirow[b]{2}{*}{ Fraction type } & \multicolumn{4}{|c|}{ OD x mm2 } \\
\hline & & & $\begin{array}{l}\text { Beta- } \\
\text { tubulin }\end{array}$ & $\begin{array}{l}\text { Alpha- } \\
\text { tubulin }\end{array}$ & Actin & Sum \\
\hline \multirow{5}{*}{$\begin{array}{l}\text { Root of } 45 \\
\text { hours }\end{array}$} & 1 & Homogenate & 0.473 & 0.201 & 0.074 & 0.748 \\
\hline & 2 & $250 \mathrm{xg}$ supernatant & 0.071 & 0.046 & 0 & 0.117 \\
\hline & 3 & $250 \mathrm{xg}$ pellet & 0.515 & 0.187 & 0 & 0.702 \\
\hline & 4 & $27000 \mathrm{xg}$ supernatant & 0.263 & 0.127 & 0.119 & 0.509 \\
\hline & 5 & $27000 \times$ xg pellet & 0.513 & 0.257 & 0.008 & 0.778 \\
\hline \multirow{5}{*}{$\begin{array}{l}\text { Embryo of } 69 \\
\text { hours }\end{array}$} & 1 & Homogenate & 0.216 & 0.107 & 0 & 0.323 \\
\hline & 2 & $250 \mathrm{xg}$ supernatant & 0.045 & 0.023 & 0 & 0.068 \\
\hline & 3 & $250 \times g$ pellet & 0.401 & 0.174 & 0.012 & 0.587 \\
\hline & 4 & $27000 \mathrm{xg}$ supernatant & 0.456 & 0.204 & 0 & 0.66 \\
\hline & 5 & $27000 \times$ xg pellet & 0.497 & 0.128 & 0 & 0.625 \\
\hline \multirow{5}{*}{$\begin{array}{l}\text { Prophylls of } \\
69 \text { hours }\end{array}$} & 1 & Homogenate & 0.849 & 0.274 & 0.083 & 1.206 \\
\hline & 2 & $250 \mathrm{xg}$ supernatant & 0.204 & 0.063 & 0 & 0.267 \\
\hline & 3 & $250 \mathrm{xg}$ pellet & 1.185 & 0.413 & 0.094 & 1.692 \\
\hline & 4 & $27000 \mathrm{xg}$ supernatant & 0.554 & 0.201 & 0.191 & 0.946 \\
\hline & 5 & $27000 \mathrm{xg}$ pellet & 0.473 & 0.201 & 0.074 & 0.748 \\
\hline
\end{tabular}

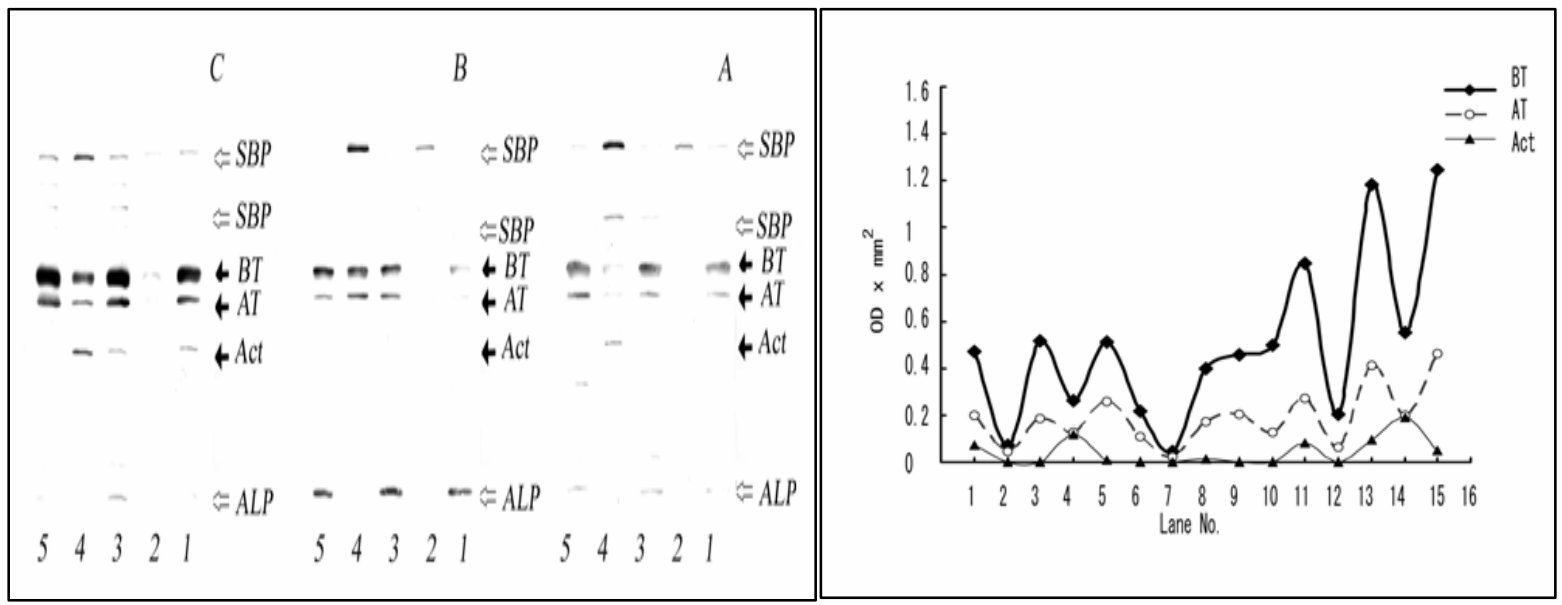

Figure 3. Western blot analysis of cytoskeleton proteins in roots of 45 hours germinated Alaska pea seeds (A), embryos of 69 hours germinated Alaska pea seeds (B) and prophylls of 69 hours germinated Alaska pea seeds (C). lanes correspond to: (1) original homogenate; (2) $250 \mathrm{xg}$ supernatant; (3) $250 \mathrm{xg}$ pellet; (4) $27000 \mathrm{xg}$ supernatant; (5) $27000 \mathrm{xg}$ pellet. Closed arrow point to the positions of Act (actin; $42 \mathrm{kDa}$ ), AT ( $\alpha$-tubulin; $46 \mathrm{kDa}$ ) and BT ( $\beta$-tubulin; $50 \mathrm{kDa}$ ). Open arrows point to streptavidin-binding proteins (SBP), and actin-like proteins (ALP).
Figure 4. Quantification of Figure 3. lanes (1 5) relationship between individual cytoskeleton protein extracted from roots of 45 hours germinated Alaska pea seeds; lanes (6 10) relationship between individual cytoskeleton protein extracted from embryos of 69 hours; lanes (11 15) relationship between individual cytoskeleton protein extracted from prophylls of 69 hours germinated Alaska pea seeds. Lanes (1, 6 and 11) original homogenate; (2, 7 and 12) 250 $\mathrm{xg}$ supernatant; (3, 8 and 13) $250 \mathrm{xg}$ pellet; $(4,9$ and 14) $27000 \mathrm{xg}$ supernatant; (5, 10 and 15) $27000 \mathrm{xg}$ pellet. BT, At, and Act refer to $\beta$ tubulin, $\alpha$-tubulin, and actin, respectively. 
Table 3. Abundance of different cytoskeleton proteins in stems, cotyledonary stalks and roots of 69 hours of germinated Alaska pea seeds. The individual band corresponding to alpha-, beta-tubulin and actin from Figure 5 were quantified by densitometry and expressed as OD x area of band. "Sum" indicates the summation of all cytoskeleton proteins in each fraction.

\begin{tabular}{|c|c|c|c|c|c|c|}
\hline \multirow[b]{2}{*}{ Tissue Type } & \multirow{2}{*}{$\begin{array}{l}\text { Lane } \\
\text { No. }\end{array}$} & \multirow[b]{2}{*}{ Fraction type } & \multicolumn{4}{|c|}{ OD $\times \mathrm{mm} 2$} \\
\hline & & & $\begin{array}{l}\text { Beta- } \\
\text { tubulin }\end{array}$ & $\begin{array}{l}\text { Alpha- } \\
\text { tubulin }\end{array}$ & Actin & Sum \\
\hline \multirow{5}{*}{$\begin{array}{c}\text { Stems of } 69 \\
\text { hours }\end{array}$} & 1 & Homogenate & 1.41 & 0.632 & 0.423 & 2.465 \\
\hline & 2 & $250 \mathrm{xg}$ supernatant & 0.542 & 0.14 & 0 & 0.682 \\
\hline & 3 & $250 \times g$ pellet & 1.403 & 0.653 & 0.219 & 2.275 \\
\hline & 4 & $27000 \mathrm{xg}$ supernatant & 0.892 & 0.294 & 0.437 & 1.623 \\
\hline & 5 & $27000 \times$ xg pellet & 1.213 & 0.523 & 0.395 & 2.131 \\
\hline \multirow{5}{*}{$\begin{array}{c}\text { Cotyledonary } \\
\text { stalks of } 69 \\
\text { hours }\end{array}$} & 1 & Homogenate & 0 & 0 & 0 & 0 \\
\hline & 2 & $250 \mathrm{xg}$ supernatant & 0 & 0 & 0 & 0 \\
\hline & 3 & $250 \mathrm{xg}$ pellet & 0.1 & 0.01 & 0 & 0.11 \\
\hline & 4 & $27000 \mathrm{xg}$ supernatant & 0.024 & 0 & 0 & 0.024 \\
\hline & 5 & $27000 \times$ xg pellet & 0 & 0 & 0 & 0 \\
\hline \multirow{5}{*}{$\begin{array}{c}\text { Roots of } 69 \\
\text { hours }\end{array}$} & 1 & Homogenate & 0.013 & 0.011 & 0 & 0.024 \\
\hline & 2 & $250 \mathrm{xg}$ supernatant & 0.013 & 0 & 0 & 0.013 \\
\hline & 3 & $250 \mathrm{xg}$ pellet & 0.284 & 0.171 & 0 & 0.455 \\
\hline & 4 & $27000 \mathrm{xg}$ supernatant & 0.08 & 0.015 & 0 & 0.095 \\
\hline & 5 & $27000 \times$ x pellet & 0.142 & 0.034 & 0 & 0.176 \\
\hline
\end{tabular}

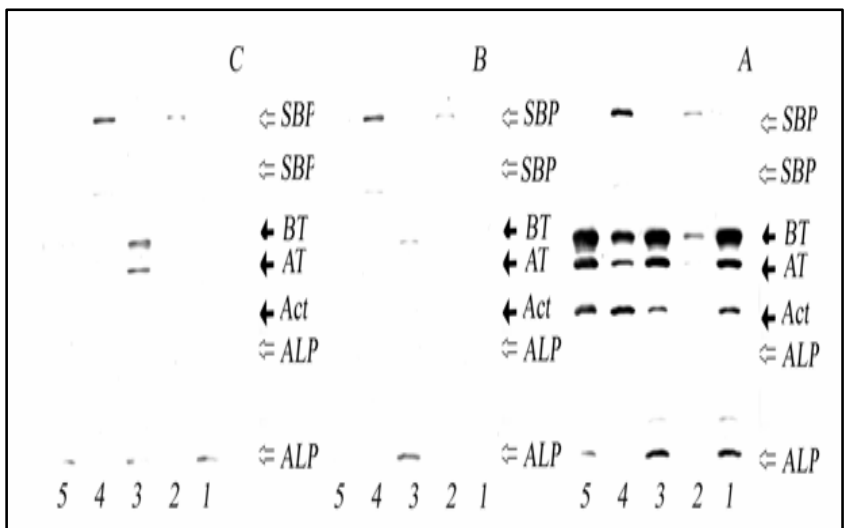

Figure 5. Western blot analysis of cytoskeleton proteins in stems of 69 hours germinated Alaska pea seeds (A), cotyledonary stalks of 69 hours germinated Alaska pea seeds (B) and roots of 69 hours germinated Alaska pea seeds (C). lanes correspond to: (1) original homogenate; (2) $250 \mathrm{xg}$ supernatant; (3) $250 \mathrm{xg}$ pellet; (4) $27000 \mathrm{xg}$ supernatant; (5) $27000 \mathrm{xg}$ pellet. Closed arrow point to the positions of Act (actin; $42 \mathrm{kDa}$ ), AT ( $\alpha$-tubulin; 46 $\mathrm{kDa})$ and $\mathrm{BT}(\beta$-tubulin; $50 \mathrm{kDa})$. Open arrows point to streptavidin-binding proteins (SBP), and actin-like proteins (ALP).
Figure 6. Quantification of Figure 5. lanes (1 5) relationship between individual cytoskeleton protein extracted from stems of 69 hours germinated Alaska pea seeds; lanes (6 10) relationship between individual cytoskeleton protein extracted from cotyledonary stalks of 69 hours germinated Alaska pea seeds; lanes (11 15) relationship between individual cytoskeleton protein extracted from roots of 69 hours germinated Alaska pea seeds. lanes: (1, 6 and 11) original homogenate; (2, 7 and 12) $250 \mathrm{xg}$ supernatant; (3, 8 and 13) $250 \mathrm{xg}$ pellet; (4, 9 and 14) 27000 $\mathrm{xg}$ supernatant; $(5,10$ and 15) $27000 \mathrm{xg}$ pellet. BT, At, and Act refer to $\beta$-tubulin, $\alpha$-tubulin, and actin, respectively. 


\section{Discussion}

Alpha-tubulin, beta-tubulin and actin are predominant in 30 hours germinated Alaska pea (Figure 1A), indicating the importance of these components in the early stage of germination of Alaska pea, whereas many pivotal proteins expressed, e.g. $49 \mathrm{kDa}$ apyrase (Moustafa et al. 2003). It is expect that there to be little sedimentabe tubulin and actin in $250 \mathrm{xg}$ and $27000 \mathrm{xg}$ supernatant under the same condition because almost all of these components retained in the pellet of $250 \mathrm{xg}$ and $27000 \mathrm{xg}$ (Figure 1A; lanes 2 and 4). Actin was the major cytoskeleton proteins to be found in cytoskeleton fractions isolated in cytoskeleton-stabilizing buffer and this in accordance with data using different extraction buffers (Hesketh and Pryme 1988; Lin 1982). Additionally, in these fraction, actin-like protein, (ALP) associate with the cytoskeleton forming a complex structure might also have some role in this stage. Cytoskeleton proteins in 30 germinated embryos present in a high amount (Table 1 and Figure 1), what the importance of theses components? Embryo consider one of the distinctive regions of plants having a capacity for continuous growth and their developmental activity generates the majority of plant organs. It is confirmed that microtubules organize the positioning of multiprotein cellulose synthase complexes at the plasma membrane so it determine the site of primary cell wall biosynthesis (Paradez et al. 2006). Sheetz and Spudich (1983a,b) reported that myosin molecules can walk on the F-actin cables and the interaction of actin and myosin can be visualized directly with a fluorescence microscope in Nitella cells. The polar distrubution of an auxin transport protein may be controlled by the cytoskelton proteins (Muday et al. 2000) and a high amount of alpha- and beta-tubulin in early stage of pea seedlings may have a role in cell differentiation and morphogenesis. Cytoskeleton proteins important for a wide range of cellular functions, which include cell division, intracellular transport, organelle positioning and generating of cell polarity, and any changes in the spatial organisation of microtubules will lead to disturbances of cell cycle progression (Yemets et al. 2005).

Since the amount of cytoskeleton proteins in root germinated for 69 hours less than 45 hours (Figures 3 and 5), this most likely those cytoskeleton proteins important for growth in the early stage of the root mrophogensis and less important at the late stage. Shevchenko et al. (2008) proved that the cytoskeleton protein have a role in gravisensing of the root elongation zone in Arabidopsis thaliana plants. Not only cytoskeleton proteins change with the age but also chemical lignin, root system morphology and pulling strength were related to seedling age (Scippa et al. 2006).

At the consequent stages of developmental growth of Alaska pea seeds, the amount of cytoskeleton protein in total embryo of 69 hours germinated seeds, less than 45 and 30 hours (Table 1, 2 and 3). Meristematic region of 69 hour germinated Alaska pea (Figure 5A) contains the bulk of cytoskeleton proteins than any other harvested parts and this in accordance with the recent data that propose final signaling targets are most likely cytoskeletonassociated proteins (Wasteneys and Yang 2004) and organized filamentous actin control the focal assembly of exocytotic vesicles at the apices of growing tips and trichome morphogensis (Szymanski et al. 1999; Vidali et al. 2001). In addition to the known cytoskeleton proteins, there are two different molecular weight of streptavidinbinding proteins (SBP); $78 \mathrm{kDa}$ and 110 $\mathrm{kDa}$ which identified previously (Shibata et al.1999; Moustafa et al. 2003). These $\mathrm{SBP}_{\mathrm{s}}$ predominant in all fractions includes 30 hours, 45 hours germinated Alaska pea and both in prophylls and stem of 69 hours, and probably involved in the organization of Alaska pea.

\section{References}

Aaziz R, Dinant S, Epel BL (2001) Plasmodesmata and plant cytoskeleton. Trends Plant Sci 6: 326-330.

Abe S, Takeda J (1986) Possible involvement of calmodulin and the 
cytoskeleton in electrofusion of plant protoplasts. Plant Physiology 81: 1151-1155

Abe S, Davies E (1991) Isolation of Factin from pea stems: Evidence from fluorescence Protoplasma 163: 51-61

Abe S, Davies E (1995) Methods for isolation and analysis of the cytoskeleton. In Galbraith D.W., Bourque D.P., Bohnert H.J. (Eds), Methods in Plant Cell Biology, vol.50, Academic Press, New York, pp.223-236

Abe S, Takeda J (1989) Promotion by calcium ions and cytochalasin D of the rounding up process (spherulation) of electrofused barley protoplasts and its relation to the cytoskeleton. Journal of Experimental Botany 40: 819-826

Balus` ka F, Salaj J, Mathur J, Braun M, Jasper F, S amaj J, Chua N-H, Barlow PW, Volkmann D (2000) Root hair formation: F-actindependent tip growth is initiated by local assembly of profilin-supported F-actin meshworks accumulated within expansin-enriched bulges. Dev Biol 227: 618-632.

Bershadsky AD, Vasilev JM (1988) Cytoskeleton. In: Siekevitz P, ed. Cellular organelles. New York, London: Plenum Press

Boevink P, Oparka K, Cruz SS, Martin B, Betteridge A, Hawes C (1998) Stacks on tracks: the plant Golgi apparatus traffics on an actin/ER network. Plant J 15: 441-447.

Braun M, Hauslage J, Czogalla A, Limbach C (2004) Tip-localized actin polymerization and remodeling, reflected by the localization of ADF, profilin and villin, are fundamental for gravity-sensing and polarized growth of characean rhizoids. Planta 219: 379-388.

Cyr RJ (1994) Microtubules in plant morphogenesis: Role of the cortical array. Annu Rev Cell Biol 10: 153 180

DePina AS, Langford GM (1999) Vesicle transport: the role of actin filaments and myosin motors. Microsc Res Tech 47: 93-106

Griffith LM, Pollard TD (1978) Evidence for actin filament microtubule interaction mediated by microtubule-associated proteins. Journal of Cell Biology 78: 958-965

Hepeler PK, Palevitz BA, Lancelle SA, Mccauley MM, Lichtscheid I (1990) Cortical endoplasmic reticulum in plants. Journal of Cell Science 96: 355-73

Hesketh JE, Pryme IF (1988) Evidence that insulin increases the proportion of polysomes that are bound to the cytoskeleton in $3 \mathrm{~T} 3$ fibroblasts. FEBS Letters 231: 62-66

Hwang JU, Suh S, Yi HJ, Kim J, Lee Y (1997) Actin filaments modulate both stomatal opening and inward $\mathrm{K}+$-channel activities in guard cells of Vicia faba L. Plant Physiol 115: 335-342.

Lin JC (1982) Mapping structural proteins of cultured cells by monoclonal antibodies. Cold Spring Harb Symb Quant Biol 46: 769-783

Mathur J, Mathur N, Hülskamp M (2002) Simultaneous visualization of peroxisomes and cytoskeletal elements reveals actin and not microtubule-based peroxisome motility in plants. Plant Physiol 128: 1031-1045.

Ma YZ, Yen LF (1988) The presence of myosin and actin in pollens and their role in cytoplasmic streaming. Acta Bot Sin 30: 285-291.

McIntosh JR (1994) The roles of microtubules in chromosome movement. In Hyams, J.S., Lloyd, C.W. (eds.): "Microtubules," New York:Wiley-Liss, pp. 413-434.

Moosker MS, Tilney LG (1975) Organization of an actin filamentmembrane complex: Filament 
polarity and membrane attachment in the microvilli of intestinal epithelial cells. Journal of Cell Biology 67: 725-743.

Moustafa MFM, Motohito Y, Abe S, Davies E (2003) Changes in isotypes and enzyme activity of apyrase during germination of dark-grown pea (Pisum sativum L. var. Alaska) seedlings. Physiologia Plantarum 119: 146-154.

Muday GK, Hu S, Brady SR (2000) The Actin Cytoskeleton May Control the Polar Distribution of an Auxin Transport Protein. Gravitational and Space Biology Bulletin 13 (2): 75-83

Paradez A, Wright A, Ehrhardt DW (2006) Microtubule cortical array organization and plant cell morphogenesis. Curr Opin Plant Biol 9: 571-8.

Scippa GS, Di Michele M, Di Iorio A, Costa A, Lasserre B, Chiatante D (2006) The Response of Spartium junceum Roots to Slope: Anchorage and Gene Factors. Annals of Botany 97: 857-866.

Sheetz MP, Spudich JA (1983a) Movement of myosin-coated fluorescent beads on actin cables in vitro. Nature 303: 31-35.

Sheetz MP, Spudich JA (1983b) Movement of myosin-coated structures on actin cables. Cell Motil 3: 485-489.

Shevchenko G, Kalinina Y, Kordyum E (2008) Role of cytoskeleton in gravisensing of the root elongation zone in Arabidopsis thaliana plants. Cell Biology International 32: 560562.

Shibaoka H (1994) Plant hormoneinduced changes in the orientation of cortical microtubules: Alterations in the cross-linking between microtubules and the plasma membrane. Annu Rev Plant Physiol, Plant Mol Biol 45: 527-544.

Shibata K, Morita Y, Abe S, Stanković B, Davies E (1999) Apyrase from pea stems: Isolation, purification, characterization and identification of a NTPase from the cytoskeleton fraction of pea stem tissue. Plant Physiol Biochem 37: 881-888

Solomon F, Magendantz M, Salzman A (1979) Identification with cellular microtubules of one of the coassembling microtubule-associated proteins. Cell 18: 431-438.

Szymanski DB, Marks MD, Wick SM (1999) Organized F-actin is essential for normal trichome morphogenesis in Arabidopsis. Plant Cell 11: 23312347.

Van Gestel K, Kohler RH, Verbelen JP (2002) Plant mitochondria move on F-actin, but their positioning in the cortical cytoplasm depends on both F-actin and microtubules. J Exp Bot 53: 659-667.

Vidali L, McKenna ST, Hepler PK (2001) Actin polymerization is essential for pollen tube growth. Mol Biol Cell 12: 2534-2545.

Walker JH, Boustead CM, Witzemann V, Shaw G, Weber K, Osborn M (1985) Cytoskeletal proteins at the cholinergic synapse: distribution of desmin, actin, fodrin, neurofilaments, and tubulin in Torpedo electric organ. European Journal of Cell Biology 38: 123-33.

Wasteneys GO, and Yang Z (2004) New Views on the Plant Cytoskeleton. Plant Physiology 136: 3884-3891.

Williamson RE (1991) Orientation of cortical microtubules in interphase plant cells. Int Rev Cytol 129: 135206.

Yemets A, Sheremet Y, Blume Y (2005) Does tubulin phosphorylation correlate with cell death in plant cells? BMC Plant Biology 5, Suppl+1, S36. 